\title{
Modeling the Relationships among Self Regulated Learning Strategies, Goal Orientation and Academic Achievement with Independent School Students in Qatar
}

\author{
Dr. Adel Saad Youssef Khedr \\ Associate Prof. of Educational Psychology \\ Faculty of Education, Zagazig University, Egypt. \\ Educational and psychological consultant \\ Al-olla Educational Institute - State of Qatar
}

\section{Abstract}

The aims of this study are to investigate the differences between Qatari and non-Qatari students in self regulated learning strategies, goal orientation and academic achievement; study the role of self regulated learning strategies and goal orientation as predictors of academic achievement. Moreover, the intention is to identify the structure model which illustrates the direct and the indirect effects of self regulated learning strategies and goal orientation on academic achievement. The participants were 214 students from two secondary independent schools in Qatar (131Qatari and 83 non-Qatari students), their ages range from 15-18 years (Mean=15.93, SD=0.83). The participants completed self regulated learning strategies questionnaire (alpha $=0.95$ ), goal orientation scale (Alpha $=0.87$ ). Their academic achievement in the four core subjects: math, science, Arabic and English was recorded. ANOVA, Linear Regression Analyses and Structure Equation Model were used to analyze the data. The findings indicated that Qatari students showed higher level of social goal orientation than non- Qatari students. No significant differences between Qatari and non- Qatari students in self regulated learning strategies, other goal orientations and academic achievement were found. However, the higher achieving students showed higher levels of self regulated learning strategies and goal orientations than the lower achieving students. Moreover, goal orientation, self regulation of cognitive strategies, behavior strategies and environmental strategies are significant predictors of academic achievement. The findings showed that there was a significant structure model that illustrates the direct and the indirect effects of self regulated learning strategies and goal orientation on academic achievement. Training programs of self regulated learning strategies and goal setting should be taken into account with children, adolescents and university students to enhance and improve their self regulated learning strategies, goal setting and academic performance.

Keywords: Self regulated learning Strategies, Goal orientation, Academic achievement.

Any correspondence to this article should be sent to Dr. Adel Khedr, E-mail: adelk22@yahoo.com. 


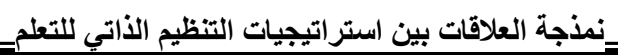

Modeling the Relationships among Self Regulated Learning Strategies, Goal Orientation and Academic Achievement with Independent School Students in Qatar

\author{
Dr. Adel Saad Youssef Khedr \\ Associate Prof. of Educational Psychology \\ Faculty of Education, Zagazig University, Egypt. \\ Educational and psychological consultant \\ Al-olla Educational Institute - State of Qatar
}

\title{
Introduction
}

After a comprehensive review of traditional educational system in Qatar, His Highness the prince of Qatar declared a decree number (37) for the year of 2002 to construct the Higher Supreme Educational Council and The different boards which belongs to this council, in order to put different efforts of educational reform into practice. As a result of that the new initiative of educational reform has been presented as education for a new era. The new type of schools have been set up, some of these schools were Ministry of Education schools. They are called Independent schools. Each school has a principal operator who is responsible for employing his administration and his academic staff according to the police of the Higher Supreme Educational Council. The principal operator and his team lead the educational system (Supreme educational council, 2007).

Since the academic year 2004-2005, the Evaluation Institute in Qatar has conducted a national assessment every year in the four core subjects: Arabic, English, Science and Math. In reviewing three annual reports of the national assessment ( Academic years of 2004-2005, 2005-2006, 2006-2007), the researcher noticed that the independent schools outperformed the Ministry of education, and privet schools in the former subjects. There is no indication of the differences between Qatari and non Qatari students ( particularly other Arab students) in academic achievement, or personal characteristics, such as self regulated learning strategies and goal orientation. This motivated the researcher to study the differences between Qatari and non Qatari students studding at Qatari Independent Schools.

Michael et al. (2007) investigated the progress in international reading literacy (PIRLS), they surveyed 215,000 students across 40 countries and 5 Canadian territories. Qatar had participated in this study. It assesses a range of reading comprehension strategies for two major reading purposes: Literacy and information. Moreover the effect of home, school and national influences on how well students learn to read. The findings showed that Qatari students performed substantially better than those in Arab states, and right below the Islamic, European and Asian countries participating in PIRLS. Qatari

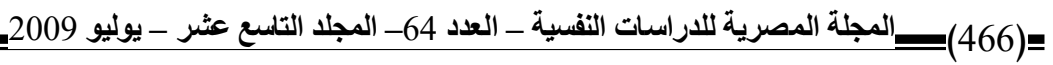


students outperformed the Kyrgyz Republic students only. Furthermore, the findings indicated that Qatari boys report a high number of hours per day spent watching television and playing electronic games compared to the cross-national average of all countries participating in PIRLS.

This finding is important because there is a negative correlation between playing games, watching television for many hours and reading achievement. This may be leads to their lower level of self regulated learning strategies and their lower ability to seat goals for themselves and strive to achieve these goals. (Education institute, 2007).

The organization for economic co-operation and development (OECD) conducting the international study (PISA 2006), with students from 56 countries, (6265) Qatari students participated in this study. It measures the proficiency of 15-year-old students in three subjects: mathematics, science and reading, focusing on their ability to apply learning in a real-world context. The findings showed that Finland was ranked first in science and math, while Korea was ranked first in reading. The performance of Qatari students in all three subjects were well below those of the industrialized OECD member countries. The findings indicated that the non-Qatari students in Qatari schools outperformed Qatari students in the three subjects (Evaluation Institute, 2006).

Although the international studies compared Qatari students academic performance with the international students performance in the three subjects, they ignored students self regulated learning strategies and goal orientation. These findings led the researcher to identify the difference between Qatari and non Qatari students in academic achievement, self regulated learning strategies and goal orientation; and to identify these factors as predictors of academic achievement in Qatari independent schools. Furthermore to focus on modeling the relationships among these factors in a Qatari context.

Many researchers would agree that identifying students' characteristics, strengths, and particularly their ability to regulate their learning, to set goals for themselves and to build relationships with teachers and peers could improve their academic achievement.

Students can increase their self confidence and academic ability if they have the ability to self regulate their learning and to set different goals for their future (Brannigan, 2007).

The main argument is that learning how to study effectively and how to regulate learning at secondary education and university levels are related to curriculum contents, achievement goal orientation, learning processes and academic achievement (Wingate, 2006).

The effective approaches to enhance learning at different educational stages depend on students' abilities to set goals for themselves and regulate

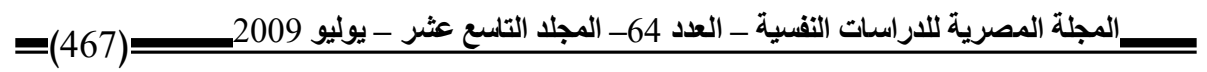


their learning. For example it is important for study and reading skills instructors to consider the specific goals for reading when advising their students. Reading and study skills courses as well as academic assistance programs help students set goals for themselves and to become self-regulated learners (Linderholm, 2006)

Identifying self regulated learning indicates to the role of cognitive process, meta cognition strategies and motivation (Zimmarman, 1990). Although the relationships among self regulated learning strategies, goal orientations and achievement had received several attention in foreign culture, they have not received the same attention in Arabic culture particularly in Qatar.

\section{Purpose}

The purpose of this study was to investigate the differences between Qatari and non-Qatari students in self regulated learning strategies, goal orientation, and academic achievement. Furthermore, the intention is study the differences between lower achieving and higher achieving students in self regulated learning and goal orientation. Moreover, the research will investigate self regulated learning strategies and goal orientation as predictors of academic achievement; and finally investigate the construct structure model of self regulated learning, goal orientation and academic achievement.

\section{Research Questions}

The problem of this research can be stated in the following questions:

1- Are there any significant differences between Qatari and non Qatari students in self regulated learning strategies, goal orientation and academic achievement?

2- Are self regulated learning strategies and goal orientations significant predictors of academic achievement?

3- Are self regulated learning strategies significant predictors of goal orientation?

4- Is there a construct model illustrates the direct and the indirect effects among self regulated learning strategies, goal orientation and academic achievement?

\section{Significance of the Study}

This study will illustrate and provide the psychologists and those who work in the area of education some information and evidences which related to self regulated learning strategies, goal orientation and academic achievement in a new cultural context: Qatari context. These information and evidences could help in improving students self regulated learning strategies, the way of goal setting, therefore their academic achievement particularly in the four core subjects: Math, Science, Arabic and English.

\section{Self Regulated Learning Strategies (SLR), and academic achievement}

Self -regulated learning (SRL) refers to the interaction of personal, 
behavioral and contextual factors to give learners the opportunity to set goals for their learning, regulate, plan, monitor and control their learning (Pintrich, 1999, Zimmerman, 2000, Nikos and George, 2005).

Zemarman (1989, p329) indicated that self regulated learning includes learners participation effectively in their learning behaviorally, motivationally and meta cognitively through feedback. Self regulated learning is an active constructive process where by learners set goals for their learning and monitor, regulate and control their cognition, motivation and behavior, guided and constrained by their goals and the contextual features of the environment (Pintrich and Zusho,2002, p64, Zimmerman, 2002 \& Wolters, et al., 2003, p2).

The main strategies of self regulated learning include: self evaluation, organization and transfer, setting goals and planning, information seeking, record keeping, environmental structure, self reinforcement, rehearsal and help seeking, and reviewing record such as notes, books, and previous tests. (Zemarman, 1989, 2000, and Purdie\& Hattie, 1996,p847).

A theoretical basis for the development of self-regulated learning model illustrates the interaction of personal, contextual, and behavioral factors to give learners an opportunity to control, regulate, monitor and improve their learning (Pintrich, 1999, Zimerman, 2000, Nikos and george, 2005). Although each model of SRL has proposes independent constructs, they share many basic assumptions of self-regulated learning (Zimmerman, and Schunk 2001). These assumptions include: first students are active, constructive, participants in the learning process, they construct their own meanings, goals, and strategies, using information available from both the internal and external environment. Second, learners have the ability to monitoring, controlling, and regulating aspects of their own cognition, motivation, behavior, and the learning environment. Third, individuals developmental, biological constraints can interfere with a learners ability to monitor or control their cognition, motivation, behavior, fourth, learners set goals to strive for in their learning, monitors progress toward these goals and then adapt and regulate cognition, motivation, behavior, and environment to achieve the goals, finally, self regulated activities are mediators between environmental and personal characteristics and actual achievement. (Zimmerman, 2001, 2002, Pintrich 2000, Rogers, et. al. 2002).

Many psychologists confirmed that effective learning requires learners to self- regulate their cognition, motivation and behavior (Zimmerman, 1989). Furthermore, Pintrich \& De Groot (1990) found a positive relationship between self regulated learning and achievement. Learners can develop their self-regulated learning through observe and consider their own behavior and acts upon what has been learned, enabling them to learn, to decrease negative

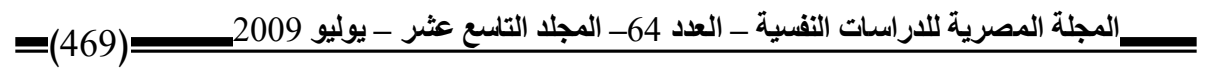


behaviors and increase positive behaviors (Reis, 2004).

Wolters, et al.( 2003,p 4-5) argued that there are a significant relationship between self -regulated learning strategies, academic achievement, and learning performance

Learners modify their study strategies so that they are in line with the cognitive processing demands of tests and that performance is mediated by the study strategies that are used (Roos 2006).

Masui (2005) with 141 university students found a significant effects of a training programs of self-regulated learning on academic performance, improve meta-cognitive knowledge as well as affective, and regulated skills. Moreover, Chih (2006) found that using self- regulated learning strategies promote students learning and satisfaction in physical education. In the same instance, Harris et al.(2008) indicated that self regulated learning strategies enhance handwriting, spelling and composition development.

As shown in previous page many researchers indicated that self regulated learning affect positively on students' academic achievement. These studies had been conducted in a foreign culture; the intention is to study these relationships with Arab students in Qatar.

\section{Goal orientation and academic achievement}

According to the achievement goal theory, learners differ from each other in their goals of achievement behavior. These differences depend on, emotional, motivational, cognitive and behavior outcomes (Howell and Watson, 2007).

Elliot and McGregor (2001) suggested that learners have four goal orientations: Mastery -approach goal orientation, refers to those seeking to learn all there is to learn. The mastery -avoidance orientation, refers to learners who motivated to avoid not learning what there is to learn; the performance -approaches orientation, refers to those motivated to perform better than others; and the performance-avoidance orientation which refers to those motivated to performing poorly relative to others. There are a growing body of researcher which extended achievement goal orientation into social domains and relationships among people suggesting a social goal orientation (Howell and Watson, 2007, Horst, et.al.2007; Ryan and Shim, 2006). In addition to academic goal orientation social goal orientation describes behavior that directed toward increasing social competence and developing relationships with others (Horst, et. al. 2007), social goals refers to people ability to set goal for themselves to achieve particular social outcomes or interactions with others. In this research social goal describes the social aim for behavior in an academic setting. It focuses on social competence.

The researcher is going to focus on five goal orientations: task goal, mastery goal, performance goal orientation, performance avoidance orientation and social goal orientation. In addition to the total score.

المجلة المصرية للاراسات النفسية ـ العدد 64- المجلد التاسع عثر - يوليو 2009 
Howell and Watson (2007) found a significant positive relationships between achievement, and both mastery goal orientation and performance goal orientation. Whereas the relationships of achievement, mastery avoidance and performance avoidance orientations were insignificant. Furthermore, Hullenman, et. al. (2008) found that initial interest and mastery goals predicted subsequent interest, and task values mediated these relationships. Furthermore, performance-approach goals and utility value predicted actual performance (e.g. course grade and coach ratings of performance). In the same instance Harackiewicz,et. al. (2008) referred to significant relationships among initial interest in studying psychology, achievement goals, situational interest, and class performance.

Witkow, and Fuligni, (2007) indicated that adolescents' nterpretations of daily school experiences and feelings mediate the relationships among achievement goals, intrinsic value of school and academic achievement.

\section{Self Regulated Learning, Goal orientation and academic achievement}

There are some evidence that goal orientations strongly related to cognitive strategies, self regulated learning and self efficiency (Pintrich\& De Groot, 1990). Self regulated learning strategies affected by motivational goal orientation (Glennon, et al., 1999). Moreover, Young (2005) found a significant relationship among cognitive evaluation, achievement goal and self regulated learning strategies in the context of the classroom.

In the same line of research Sungur (2007 a) found that intrinsic goal orientation, beliefs about value of a test control of learning beliefs and self efficacy for learning and performance were predictors of students metacognitive strategies use. Therefore, students should have motivation to use meta-cognitive strategies and engage in a task. Furthermore, Sungur (2007 b), indicated that regulation of cognitive component of meta-cognition and mastery goal orientation were the best predictors of students achievement under consequential test conditions. Whereas, under non consequential test conditions, mastery goal orientation and task value became the main reasons for students' engagement with the task.

Learners with high knowledge monitoring ability reviewed more nonsense words. The effects of motivation orientations and meta-cognitive knowledge monitoring on academic help seeking were insignificant (Katherine, 2007). Recent research has indicate to a significant relationship between metacognitive strategies, and both mastery goal orientation and performance goal orientation. Those who use deep processing strategies tend to be more mastery and performance goal orientations. Furthermore, disorganization was positively correlated with the mastery- avoidance and performanceavoidance goal orientations (Howell, 2007)

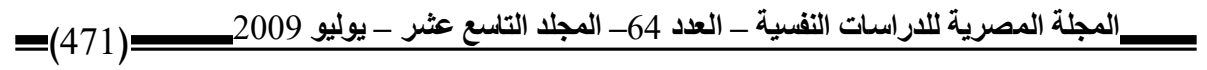


Anthony (2007) indicated that low achieving students' level of constructive activity predicted post-test performance. In addition, constructive activity was found to mediate the relationship between achievement goals and learning. However, achievement goals were not related to low achievers constructive use of help. Instead, achievement goals were related to low achievers' relative accuracy in comprehension monitoring, which in turn was related to level of constructive activity.

Previous researches in westerner countries and united state did not indicate to a consistent significant relationship between self regulated learning strategies, goal orientation and achievement.

\section{Research hypotheses}

The hypotheses of this research can be stated in the following questions:

1- There are insignificant differences between Qatari and non Qatari students in self regulated learning strategies, goal orientation and academic achievement.

2- Self regulated learning strategies and goal orientations are significant predictors of academic achievement.

3- Self regulated learning strategies are significant predictors of goal orientation.

4- There is a construct model illustrates the direct and the indirect effects among self regulated learning strategies, goal orientation and academic achievement.

\section{Method}

\section{Participants}

The pilot sample included (126) participants from Hamad Bin Abdul Bin Gassim independent secondary school, their ages range from (15) to (17) years old $(\mathrm{M}=15.77, \mathrm{SD}=0.64)$

The final sample of this study included 214 males' students. They were drawn from the first grade students of two secondary independent schools in Qatar, their ages ranged from 15 to $18(\mathrm{M}=15.93$ and $\mathrm{SD}=0.83)$ : 131 Qatari students and (83) of non-Qatari students.

\section{Materials}

\section{1- Self regulated learning strategies questionnaire}

An Arabic version of self regulated learning questionnaire included 40 items had been constructed to assess 10 self regulated learning strategies: self evaluation, organization and transfer, setting goals and planning, information seeking, record keeping, environmental structure, self reinforcement, rehearsal and help seeking, and reviewing record (notes, books, previous tests). (Zemarman, 1989, 2000, and Purdie\& Hattie, 1996, p847), 4 items for each subscale. A pole of these items based on self regulated learning strategies of Zemarman, $(1989,2000)$. Each item is rated on a response scale of 1 (strongly disagree) to 5 (Strongly agree). 
These items were reviewed by 4 experts of educational psychology; some modifications have been done for some items. The questionnaire completed by 20 students, their ages ranged from 15 to 16 years old, $(\mathrm{M}=15.8, \mathrm{SD}=0.41)$ as a preliminary trial

To identify any items which are unclear? Therefore, the researcher rewrites 3 items. The questionnaire was completed by 126 participants of first grade secondary school students (80 Qatari and 46 non- Qatari students), their ages ranged from 15 to17 years old (Mean=15.77, SD=0.64). Alpha coefficient $=0.95$.

A confirmatory factor analysis has been performed to test the questionnaire construct validity. The internal relationships among the observed variables (10 self regulated learning strategies subscales) representing the construct are examined to identify wither they assess three latent factors (cognitive and meta-cognitive strategies, behavior strategies and environmental strategies) as a first order factors and one latent factor of second order (self regulated learning strategies) or not. The findings indicated that the proposed model fit to the data (ChiSquare=31.10, $\mathrm{df}=24, \mathrm{P}$-value=0.15, RMSEA=0.049, GFI=0.95). Figure 1 shows path diagram of self regulated learning strategies.

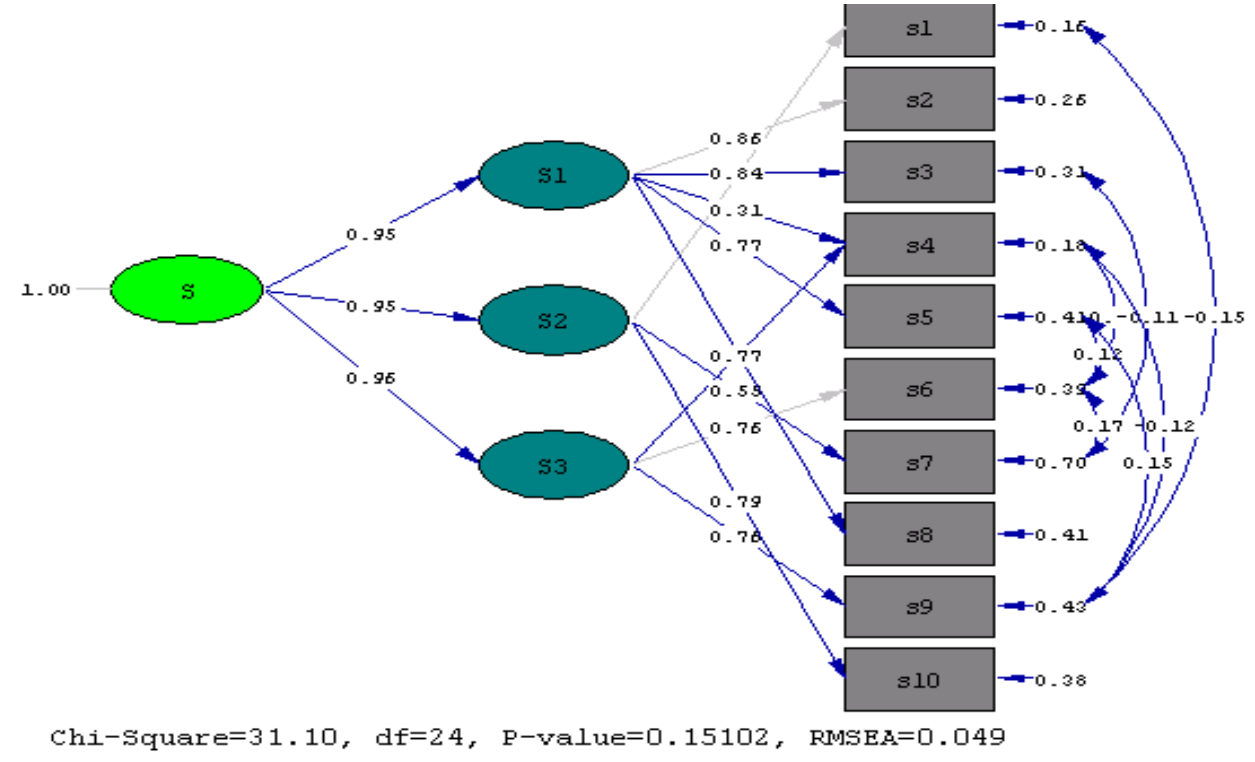

Figure 1. Path diagram of self regulated learning strategies

Key: s1 to s10 represent the observed variables of self regulated learning strategies, $\mathrm{S} 1=$ cognitive strategies, $\mathrm{s} 2=$ behavior strategies,

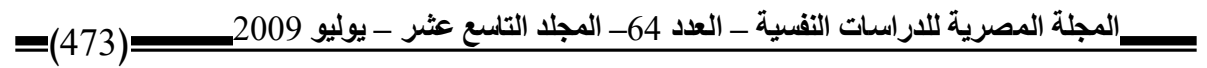


s3= environmental strategies, $S=$ the general factor of self regulated learning strategies.

\section{2- Goal orientation scale.}

To construct this scale, the researcher review literature of goal orientation and previous scales as a result the researcher identified five dimensions of goal orientation: mastery goal, task goal, performance orientation, performance avoidance and social orientation. Using literature and previous scales the total of 25 items have been written constructing the scale: 5 items for each subscale. The items are rated on a response scale of 1 (strongly disagree) to 5 (Strongly agree). These items were reviewed by 4 experts of educational psychology; some modifications have been done for some items. The scale completed by 20 students, their ages range from 15 to 16 years old, $(\mathrm{M}=15.8, \mathrm{SD}=0.41)$ as a preliminary trial to identify any items which are unclear. Therefore, the researcher rewrites 2 items. The scale was completed by 126 participants of first grade secondary school students (80 Qatari and 46 non- Qatari students), their ages ranged from 15 to17 years old (Mean=15.77, $\mathrm{SD}=0.64$ ). Alpha coefficient for the scale as all and for scale if item deleted have been performed. The findings indicated that there are 5 items which are unreliable and invalid. Reliability (Alpha) of the total scale when each of these items included in the analyses is less than the reliability when these items not included, Alpha for the total scale $=0.75$. After excluding these items alpha coefficient for the scale $=0.87$.

A confirmatory factor analysis has been performed to test the construct validity of this scale. The internal relationships among the observed variables (5 goal orientation subscales) representing the construct are examined to identify wither they assess one latent factor (Goal orientation) or not. The findings indicated that the one factor model fit to the data. (Chi-Square $=5.01, \mathrm{df}=5, \mathrm{P}$-value $=0.41495$, RMSEA=0.003). Figure 2 shows path diagram of one factor solution. 


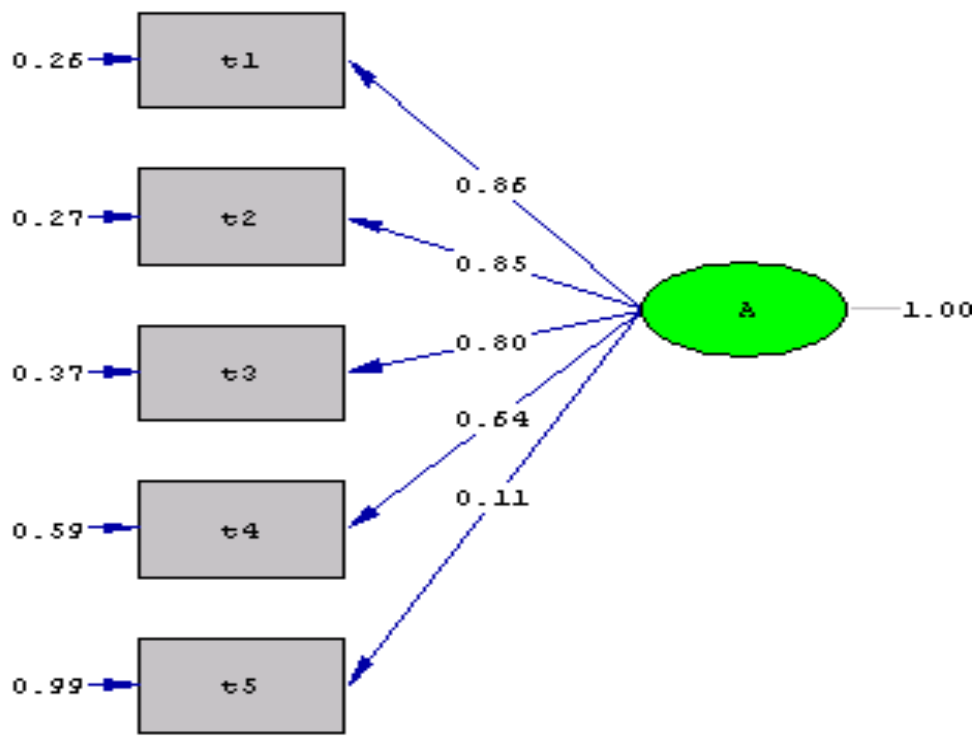

Chi-Square $=5.01, \mathrm{df}=5, \mathrm{P}$-value $=0.41495$, RMSEA $=0.003$

Figure 2. Path diagram of one factor solution for goal orientation scale

Key: $t 1=$ mastery orientation, $t 2=$ task orientation, $t 3=$ social orientation, $t 4=$ performance orientation, $t 5=$ performance avoidance. $A=$ Goal orientation.

\section{3- Academic Achievement}

Students' scores in the four core subjects: math, science, English and Arabic in the final exams of the first semester were used as an indicator of academic achievement.

\section{Procedures}

Self regulated learning questionnaire and goal orientation scale have been developed and standardized with a pilot sample of secondary school students,

The participants of this study have been drawn from two secondary independent schools in Qatar. The participants completed the materials in 30 minutes, their grades in the four core subjects: mathematics, science, English, and Arabic in the first semester were taken as an indicator of academic achievement. The data were analyzed using 


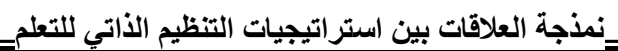

ANOVA, Linear Regression Analysis (SPSS) and Structure equation model ( Lisrel 8.8). The findings and discussion are presented below.

\section{Results}

The differences between Qatari and non- Qatari students in goal orientation, self regulated learning and academic achievement.

The analysis of variance was performed to identify the differences between Qatari and non-Qatari students in goal orientations, self regulated learning and achievement. The findings indicated that the differences in social goal orientation was significant $(\mathrm{F}=6.314, \mathrm{DF}=1$, and $\mathrm{P}=0.013$ ). Qatari students showed higher levels of social goal orientation than the non- Qatari students. The other differences were insignificant.

The differences between lower achieving and higher achieving students in goal orientation and self regulated learning strategies.

To identify the differences among lower achieving and higher achieving in self regulated learning and goal orientation, participants were divided into 4 groups. The researcher takes the highest group and the lowest group of participants in achievement. Analysis of variance was employed. The findings indicated that the difference between lower achieving and higher achieving in the different dimensions of goal orientation are significant except in the case of the social orientation: Mastery goal $(\mathrm{F}=33.871, \mathrm{DF}=1, \mathrm{P}=0.000)$, Task goal orientation $(\mathrm{F}=53.921, \mathrm{DF}=1, \mathrm{P}=0.000)$, performance orientation $(\mathrm{F}=$ 25.249, $\mathrm{DF}=1, \mathrm{P}=0.000)$, performance avoidance $(\mathrm{F}=17.325 \quad \mathrm{DF}=1$, $\mathrm{P}=0.000$ ), social orientation ( $\mathrm{F}=1.573, \mathrm{DF}=1, \mathrm{P}=0.213$ ) and the total scare $(\mathrm{F}=43.660, \mathrm{DF}=1, \mathrm{P}=0.000)$. The higher achieving students have a highest level of goal orientation than the lower achieving students.

The findings indicated that the differences between lower achieving and higher achieving students in self regulated learning strategies are significant. The higher achieving students have a highest level of self regulated learning strategies than the lower achieving students: Cognitive and meta-cognitive self regulate learning strategies $(\mathrm{F}=$ 148.233, $\mathrm{DF}=1, \mathrm{P}=0.000)$, self regulated of behavior strategies $(\mathrm{F}=$ 155.501, $\mathrm{DF}=1, \mathrm{P}=0.000$ ), self regulated of environmental strategies $(\mathrm{F}=222.300, \mathrm{DF}=1, \mathrm{P}=0.000)$.

Self regulated learning strategies as predictors of academic

المجلة المصرية للاراسات النفسية ـ العدد 64- المجلد التاسع عثر - يوليو 2009 $(476)=$ 


\section{achievement}

To identify whether self regulated learning strategies are good predictors of academic achievement or not the researcher employed the linear regression analysis and the findings indicated that: self regulated learning strategies are good predictors of academic achievement, (Model summary, $\mathrm{R}=0.862$, $\mathrm{R}$ Square $=0.744, \mathrm{SE}=5.0387$, F change $=$ 202.952, df $1=3$, df $2=210, \mathrm{P}=0.00)$.

The analysis indicated that cognitive and meta cognitive strategies $(\mathrm{B}=0.197, \mathrm{SE}=0.077, \mathrm{~T}=0.2 .564, \mathrm{P}=0.011)$, behavior strategies $(\mathrm{B}=$ $0.612, \mathrm{SE}=0.077, \mathrm{~T}=5.537, \mathrm{P}=0.000)$ and environmental strategies ( $\mathrm{B}=0.359, \mathrm{SE}=0.066, \mathrm{~T}=5.414, \mathrm{P}=0.000$ ) are good predictors of academic achievement. Table 1 shows these findings.

Table1. Coefficients of leaner regression analysis for self regulated learning strategies and achievement.

\begin{tabular}{|l|l|c|c|c|c|c||}
\hline & & $\begin{array}{c}\text { Un- } \\
\text { standardized } \\
\text { Coefficients }\end{array}$ & & $\begin{array}{c}\text { Standardized } \\
\text { Coefficients }\end{array}$ & t & Sig. \\
\hline $\begin{array}{l}\text { Mode } \\
\mathbf{l}\end{array}$ & Variables & $\mathbf{B}$ & Std. Error & Beta & & \\
\hline 1 & (Constant) & 48.121 & 2.300 & & 20.926 & .000 \\
\hline & $\begin{array}{l}\text { Cognitive-Meta } \\
\text { cognitive strategies }\end{array}$ & .197 & .077 & .197 & 2.564 & .011 \\
\hline & Behavior strategies & .612 & .110 & .330 & 5.537 & .000 \\
\hline & Environmental strategies & .359 & .066 & .396 & 5.414 & .000 \\
\hline
\end{tabular}

a Dependent Variable: Academic achievement.

The prediction formula for academic achievement in the four core subjects: Arabic, Science, Math and English can be written as shown below.

Academic Achievement $=0.197 *$ Cognitive and Meta Cognitive Strategies+ 0.612* Behavior strategies+ 0.359* Environmental Strategies +48.121

\section{Goal orientation as predictor of academic achievement}

To identify wither goal orientation predict academic achievement, the researcher used linear regression analyses, and the findings indicated that, the mastery goal orientation $(B=1.317, S E=0.163$, $\mathrm{T}=0.438, \mathrm{P}=0.000)$, and task goal orientation $(\mathrm{B}=1.396, \mathrm{SE}=0.161$, $\mathrm{T}=0.462, \mathrm{P}=0.000)$ are good predictors of academic achievement. Whereas, the other goal orientations: performance goal orientation, performance avoidance and social orientations were not good

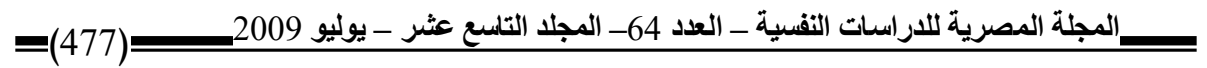


predictors of academic achievement. $(\mathrm{R}=0.870, \mathrm{R}$ square $=0.756, \mathrm{SE}=$ 4.934 Table 2 shows these findings.

Table 2. Coefficients of linear regression analysis of goal orientations and achievement

\begin{tabular}{|l|l|l|l|l|l|l||}
\hline & & $\begin{array}{l}\text { Unstandardized } \\
\text { Coefficients }\end{array}$ & & $\begin{array}{l}\text { Standardized } \\
\text { Coefficients }\end{array}$ & T & Sig. \\
\hline Model & & $\mathbf{B}$ & Std. Error & Beta & & \\
\hline 1 & (Constant) & 40.962 & 2.727 & & 15.023 & $\mathbf{. 0 0 0}$ \\
\hline & Mastery goal & 1.317 & .163 & .438 & 8.087 & $\mathbf{. 0 0 0}$ \\
\hline & Task Goal & 1.396 & .161 & .462 & 8.696 & $\mathbf{. 0 0 0}$ \\
\hline & Social goal & .175 & .149 & .055 & 1.173 & .242 \\
\hline & Performance Goal & -5.14102 & .207 & -.011 & -.248 & .804 \\
\hline & $\begin{array}{l}\text { Performance } \\
\text { avoidance }\end{array}$ & 6.33602 & .186 & .012 & .341 & .733 \\
\hline
\end{tabular}

a Dependent Variable: Academic achievement

The formula of prediction can be written as shown below: Academic achievement=1.317*Mastery Goal orientation $+1.396 *$ Task Goal orientation +40.962

Self regulated learning strategies as predictors of goal orientation

Linear regression analysis have been used to identify whither self regulated learning strategies are good predictors of goal orientation or not. The findings indicated that, the proposed model is significant, $(\mathrm{R}=$ $0.748, \mathrm{R}$ Square $=0.554, \mathrm{SE}=7.1725, \mathrm{P}=0.000)$. The finings indicated that cognitive and meta-cognitive strategies $(\mathrm{B}=0.554, \mathrm{SE}=0.110, \mathrm{~T}=$ 5.052 and $\mathrm{P}=0.000)$, and environmental strategies $(\mathrm{B}=0.200, \mathrm{SE}=$ $0.094, \mathrm{~T}=2.120, \mathrm{P}=0.035$ ) are good predictors of goal orientation.

Table 3 shows these findings.

Mathematical equation for prediction can be formulated as shown below.

Goal orientation $=0.554 *$ Cognitive strategies $+0.200 *$ Environmental strategies +32.604

Table 3. Linear regression Coefficients of self regulated learning strategies as predictors of goal orientation.

\begin{tabular}{|l|l|l|l|l|l|l|}
\hline & & $\begin{array}{l}\text { Unstandardized } \\
\text { Coefficients }\end{array}$ & & $\begin{array}{l}\text { Standardized } \\
\text { Coefficients }\end{array}$ & t & Sig. \\
\hline Model & $\mathbf{B}$ & $\begin{array}{l}\text { Std. } \\
\text { Error }\end{array}$ & Beta & & \\
\hline 1 & (Constant) & 32.604 & 3.273 & & 9.960 & .000 \\
\hline & C.\& M.C. Strategies & .554 & .110 & .509 & 5.052 & $\mathbf{. 0 0 0}$ \\
\hline & Behavior strategies & .137 & .157 & .068 & .870 & .385 \\
\hline & $\begin{array}{l}\text { Environmental } \\
\text { strategies }\end{array}$ & .200 & .094 & .203 & 2.120 & $\mathbf{. 0 3 5}$ \\
\hline
\end{tabular}

=(478)_ــالمجلة المصرية للاراسات النفسية ـ العدد 64- المجلد التاسع عثر - يوليو 2009 
a Dependent Variable: Goal orientation; independent variables: cognitive and meta-cognitive strategies, behavior strategies, an environmental strategies.

Self regulated learning strategies and goal orientation as predictors of Academic achievement

Linear regression analysis indicated that the total score of goal orientation $(\mathrm{B}=0.219, \mathrm{SE}=0.018, \mathrm{~T}=12.335$ and $\mathrm{P}=0.000)$. and that of self regulated learning strategies $(B=0.387, S E=0.041, T=9.526$ and $\mathrm{P}=0.000)$ are a significant predictors of academic achievement $(\mathrm{R}=$ 0.903 , R Square $=0.815, \mathrm{SE}=4.27, \mathrm{~F}, 464.04, \mathrm{P}=0.000$ ). Table 4 shows these findings. The mathematical formula of prediction can be formatted as follows:

Academic achievement $=0.219 *$ self regulated learning $+0.387 *$ goal orientation + 35.088.

Table 4. Coefficients of linear regression analysis of goal orientation total score and self regulated learning total score.

\begin{tabular}{|l|l|l|l|l|l|l||}
\hline & & $\begin{array}{l}\text { Unstandardized } \\
\text { Coefficients }\end{array}$ & & $\begin{array}{l}\text { Standardized } \\
\text { Coefficients }\end{array}$ & $\mathbf{t}$ & Sig. \\
\hline $\begin{array}{l}\text { Mo } \\
\text { del }\end{array}$ & Variables & $\boldsymbol{B}$ & $\begin{array}{l}\text { Std. } \\
\text { Error }\end{array}$ & Beta & & \\
\hline 1 & (Constant) & 35.088 & 2.348 & & 14.946 & $\mathbf{. 0 0 0}$ \\
\hline & Self regulated learning & .219 & .018 & .545 & 12.335 & $\mathbf{. 0 0 0}$ \\
\hline & Goal orientation & .387 & .041 & .421 & 9.526 & $\mathbf{. 0 0 0}$ \\
\hline
\end{tabular}

a Dependent Variable: Academic achievement

The structure model of self regulated learning, goal orientation and achievement.

Structure equation model (Lisrel 8.8) was performed to identify whither there are a structure casual model illustrate the direct and the indirect effects of self regulated learning strategies, goal orientations on achievement, or not.

The findings indicated that there is a structure model fit to the data and illustrates the direct and the indirect effects of self regulated learning strategies and goal orientation on academic achievement. The model showed that self regulated learning strategies mediated the relation between goal orientation and academic achievement. Furthermore, self regulated learning strategies effect directly on academic achievement. In addition goal orientation affect directly on self regulated leering strategies and indirectly on the observed variables of self regulated learning strategies, the model fit to the

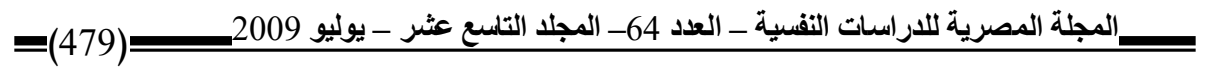




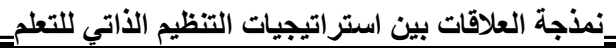

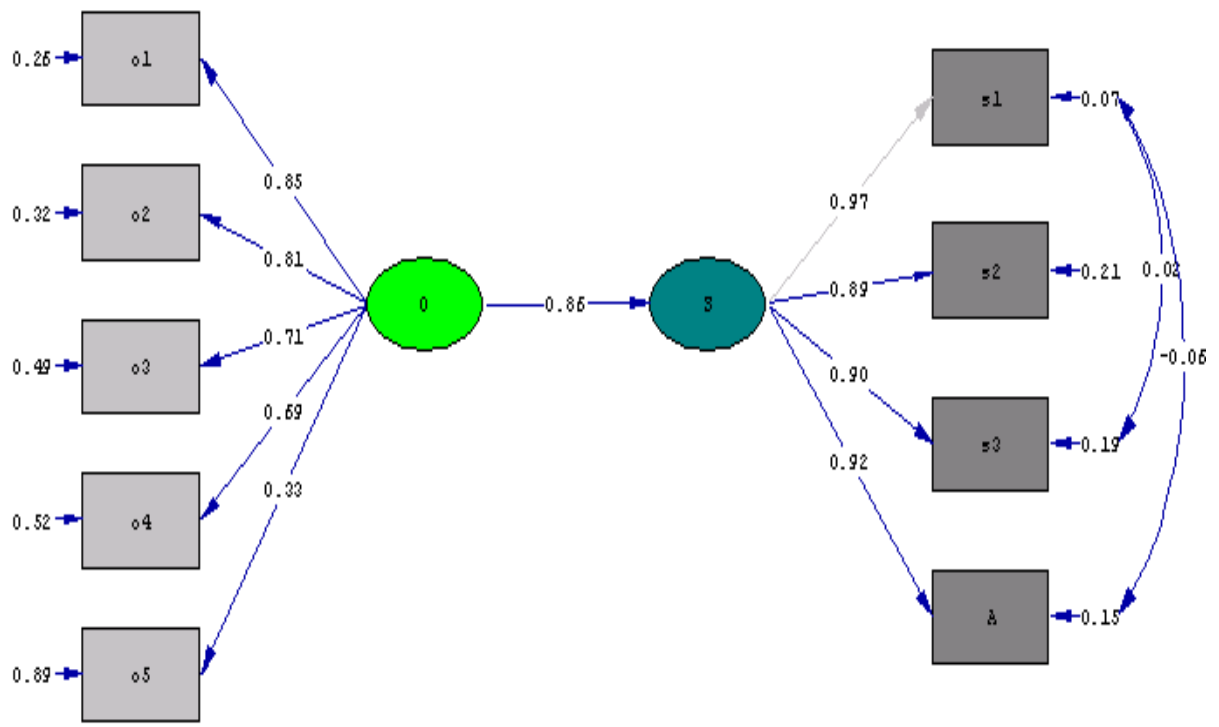

data..(Chi-Square=24.82, $\mathrm{df}=22, \mathrm{P}$-value=0.30584, RMSEA=0.025). Figure 3 shows these findings.

Figure 3. Path diagram of structure model of self regulated learning, goal orientation and achievement.

Key: o1 = Mastery goal orientation, o2 = Task goal orientation, o3= Social orientation, $o 4=$ Performance orientation, o5 = Performance avoidance, $O=$ Goal orientation, $S=$ Self regulated learning strategies. $S 1=$ Cognitive strategies, $S 2=$ Behavior strategies, $S 3=$ Environmental strategies, $A=$ Academic achievement.

\section{Discussion}

The findings indicated that Qatari students have higher level of social goal orientation than the non Qatari students. This finding may be due to the higher level of Qatari students' ability to set social goals for themselves to achieve social outcomes or interactions with others in academic setting, they are more sociable. Science they have more chances to develop their social competence than the non Qatari students. The differences in other goal orientations, self regulated learning strategies (SRL), and academic achievement were insignificant. These findings could attribute to the independent school environment and scholastic practices, further more the majority of the non Qatari students have been borne in Qatar. These findings need more investigation with a large scale of Qatari and non Qatari students. 
Self regulation of cognitive, behavior and environmental strategies as well as the total score of (SRL) are good predictors of academic achievement. It should be notice that behavior strategies are strongest predictors of academic achievement in compression to cognitive and environmental strategies. Since learners have the ability to monitor, control, and regulate aspects of their own cognition, motivation, behavior, and the learning environment; their academic achievement will be enhanced and improved. These findings agree to a great degree with the findings of Pintrich\& De Groot, (1990), Wolters, et. al., (2003); Masui, (2005), Roos, (2006), Chih, (2006). They found a significant relationship between self regulated learning strategies and academic achievement.

Furthermore mastery goal, task goal orientations and the total score of goal orientation are good predictors of academic achievement. These findings in line with the findings of Witkow and Fuligni (2008), Hullenman, et.al.(2008a), Howell(2007), found a significant relationship between goal orientation and academic achievement.

Moreover, the cognitive self regulated learning strategies, and environmental strategies are significant predictors of goal orientation. The researcher notice that cognitive and meta cognitive strategies contribute in setting goal orientations more than the environmental strategies. May be because students adapt different strategies of self regulated learning, particularly cognitive and meta cognitive ones, when setting goals for their achievement and striving to achieve these goals.

The structure equation model was in line with the previous findings since it illustrated that self regulated learning strategies (SLR) are a mediator of the relation between goal orientation and academic achievement. Further, there is a direct casual effect of goal orientation on self regulated learning strategies. In addition, goal orientation has indirect positive effect on both academic achievement and the observed variables of self regulated learning strategies. Furthermore, researches are needed with a large scale of students and many factors related to self regulated learning strategies, Goal orientation and academic performance particularly with Qatari students. Focus on training programs to develop these strategies and their goal orientation is needed. This work could be extended to primary school children; it will benefit them in advanced levels of their academic life. Children could develop good and effective self regulated learning strategies, set goals for themselves and strive to achieve these goals which will reflect positively not only on their academic achievement but also on their life style. This study gives us some evidences with Qatari and non- Qatari students in independent schools.

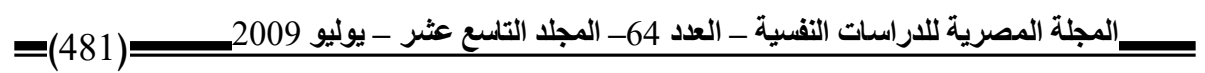




\section{References}

Anthony J. G. (2007). The influence of achievement goals on the constructive activity of low achievers during collaborative problem solving, British Journal of Educational Psychology, 77, 1,121 - 141.

Brannigan, M. (2007). A psycho-educational group model to build academic competence in new middle school students. Journal of Specialists in Group Work,32, 1, 61-70.

Chih, A.(2006). The effect of the use of self-regulated learning strategies on college students' performance and satisfaction in physical education. PH.D. thesis, Australian Catholic University, Australia.

Education institute (2007): Students in Qatar performance better than other Arab countries in global assessment of reading literacy. http://www.sec.gov.qa/content/general/detail/20349

Elliot, A. J. \& McGregor, H. A. (2001). A2x2 Achievement goal framework, Journal of Personality and Social Psychology, 80, 501-519.

Evaluation institute (2005): Schools and schooling in Qatar 2004-2005. A statistical overview of aspects of schools and schooling in Qatar. ). Supreme Educational Council, State, Qatar. www.education.gov.qa.

Evaluation institute (2006): Schools and schooling in Qatar 2004-2005. A statistical overview of aspects of schools and schooling in Qatar. ). Supreme

Educational Council, State, Qatar. www.education.gov.qa.

Evaluation Institute (2007). Knowledge and skills for new millennium. Findings from PISA for State of Qatar. Supreme Educational Council, State of Qatar. www.education.gov.qa.

Evaluation institute (2007): Schools and schooling in Qatar 2006-2007. A statisticaloverview of aspects of schools and schooling in Qatar. ). Supreme Educational Council, State, Qatar. www.education.gov.qa.

Glennon, S. , Jill, D.; Gorrell, J., Sanders, S. Body, P. \& Kamen, M.( 1999). Self- regulated learning strategies used by the learners in a learnercentered school.

Paper presented at the Annual meeting of the American Educational

Research Association (Montreal, Quebec, Canada, April 19-23.

Harackiewicz, J. M.; Durik, Amanda M.; Barron, K. E.; Linnenbrink-G., L.;\& Tauer,J.M. (2008). The role of achievement goals in the development of interest:Reciprocal relations between achievement 
goals, interest, and performance.

Journal of Educational Psychology. 100(1), 105-122.

Harris, K., Graham, S. \& Mason, L.(2008). Self regulated strategy development in writing: Story and Opinion essay writing for students with disabilities or severe difficulties in the early elementary grades. Center for accelerating student learning. Department of special education, University of Maryland. Available at outreach selfregulated strategy development.mht.

Horst, J.; Finney, S\& Barron, K., (2007). Moving beyond academic achievement goal measures: A study of social achievement goals.

Contemporary Educational Psychology, 32, 4,667-698.

Howell, A.\& Watson, D. (2007). Procrastination: Associations with achievement goal orientation and learning strategies. Personality and individual differences,43,1,176-168.

Hulleman, C. S.; Durik, A. M.; Schweigert, Shaun B.;\& Harackiewicz, J.

M. (2008). Task values, achievement goals, and interest: An integrative analysis. Journal of Educational Psychology.100(2), $398-416$

Katherine, S. (2007). Adolescents' metacognitive knowledge monitoring and academic help seeking: The role of motivation orientation.

Available at http://www.projectinnovation.biz/csj.html

Linderholm, T. ( 2006). Reading with purpose. Journal of College Reading and Learning, 36, 2, 70-80

Michael O. M., Ina V.S., and Ann M. K. (2007). PIRLS 2006 Technical Report, Chestnut Hill, MA: TIMSS \& PIRLS International Study Center, Boston College. Available at http://Pirls.bc.edu/pirls2006/teach_rpt.html.

Nikos, M. \& George, P.(2005). Students' motivational beliefs, self-regulation strategies and mathematics achievement. In Chick, H. L. \& Vincent, J L.(Eds). Proceeding of the $29^{\text {th }}$ conference of the international group for the psychology of mathematics education, 3, 321-328. Melbourne:

PME

Pintrich, P., R. (1999). The role of motivation in promoting and sustaining self - regulated learning. International Journal of Educational Research, 31, 459- 470

Pintrich, P., R.(2000). The role of goal orientation in self regulated learning, in M. Boekaerts, P., Pintrich and Zeidner, M. (Eds). Handbook of self regulation: Theory, research, and applications(13-39). San Diego, CA: Academic Press

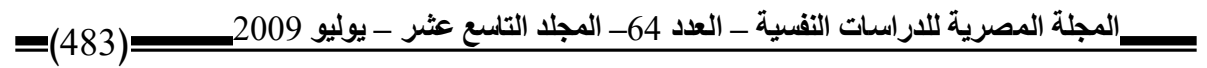


Pintrich, P. \& De Groot, E. (1990). Motivational and self-regulated learning components of classroom academic performance. Journal of Educational Psychology. 82, 33-40

Purdie, N. \& Hattie, J. (1996). Cultural differences in the use of strategies for self - regulated learning. American Educational Research Journal, $33,845-871$

Reis, S. M. (2004). Self regulated learning and academically talented students available at: mhtml:file://F:/NAGC-December 2004 Self-Regulated Learning.mht,

Roger, A. Susan, R. Jennifer, G. \& stacy, P.(2002). Do different goal-setting conditions facilitate students' ability to regulate their learning of complex science topics with River Web?. Paper presented at the annual conference of the National Educational Research Association, New Orleans, LA(April 1-5).

Ryan, A. M.\& Shim, S.O. (2006). Social achievement goals: the nature and consequences of different orientations toward social competence, Personality and Social Psychology Bulletin, 32, pp. 1246-1263.

Schunk, D. (2001). Social cognitive theory and self regulated learning. In Zimmarman, B. \& Schunk, D. (Eds.), self-regulated learning and academic achievement. Theoretical perspectives (125-152). Mawah, NJ: Erlbaum. Origins of self -regulatory competence. Educational Psychologist, 32, 195-208.

Sungur, S. (2007 a). Modeling the relationships among students' motivational beliefs, metacognitive strategy use, and effort regulation. Scandinavian Journal of Educational Research,51, 3, 315-326.

Sungur, S. (2007 b). Contribution of motivational beliefs and metacognation to students' performance under consequential and no consequential test conditions. Educational Research and Evaluation,13,2, 127-142.

Supreme Education council(2008): Education for a new Era, Wingate, V. (2006). Doing way with study skills, Teaching in higher education, 11, 4, 457-469.

Witkow, M. R.;\& Fuligni, A. J. (2007). Achievement goals and daily school experiences among adolescents with Asian, Latino, and European American backgrounds, Journal of Educational Psychology. 99(3) 584-596.

Wolters, C. Pintrich, P. \& Karabenick, S. (2003). Assessing academic selfregulated learning. Paper presented at the conference on indicators of positive development: Definitions, Measures, and Prospective Validity

المجلة المصرية للار اسـات النفسية _ العدد 64- المجلد التاسع عثر - يوليو 2009 $(484)=$ 
Young, M., R. (2005). The motivational effects of the classroom environment in facilitating self-regulated learning. Journal of Marketing Education, $27,1,40-25$.

Zimmerman, B. \& Martinez-Pons, M. (1988). Construct validation of a strategy model of student self regulated learning, Journal of Educational Psychology, 0022-0663, 80, 3.

Zimmerman, B. (1989). A social cognitive view of self-regulated academic learning, . Journal of Educational Psychology, 80, 284-290.

Zimmerman, B. (1990): Self -regulated learning and academic achievement: An overview, Education Psychologist,25,1, N.30.

Zimmerman, B. (2000). Attaining self -regulation: A social cognitive perspective. In M. Boekaerts, P., Pintrich and Zeidner, M. (Eds). Handbook of self regulation: Theory, research, and applications(1339). San Diego, CA: Academic Press.

Zimmerman, B. \& Schunk, D. (2001). Self -regulated learning and academic achievement theoretical perspectives: Mawah, NJ:Erlbaum.

Zimmerman, B. (2002). Achieving academic excellence: A self -regulatory perspective. In Boekaerts, M. , Pintrich, \& Zeidner(Eds)., Handbook of self-regulation, (13-39). San Diego, CA: Academic Press. 
نمذجة العلاقات بين استراتيجيات التظيم الأتي للتعلم وتوجه الهـف

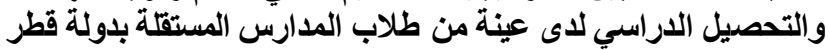

دكتور / عادل سعد يوسف خضر

أستاذ علم النفس التربوي المساعد

كلية التربية - جامعة الزقازيق

استثاري تربوي - مؤسسة العلا التعليمية- دولة قطر

ملخص البحث

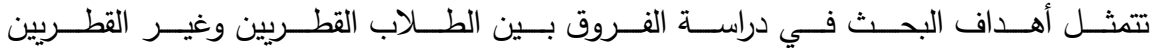

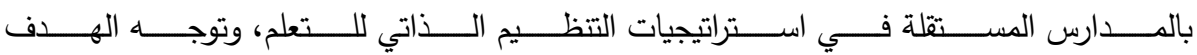

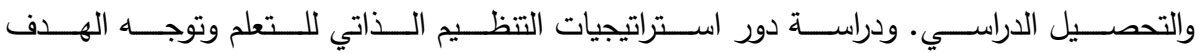

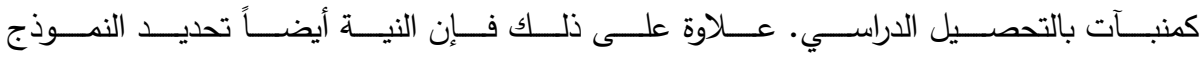

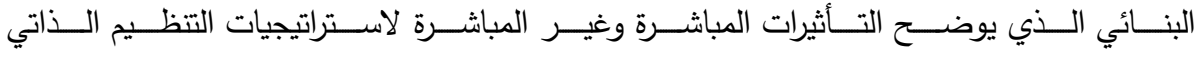

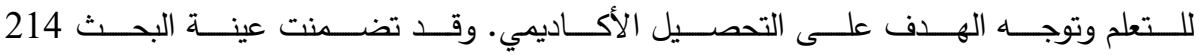

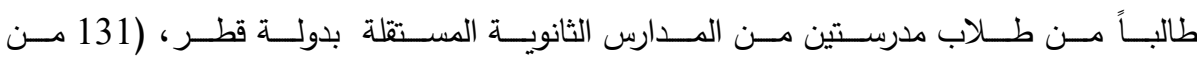

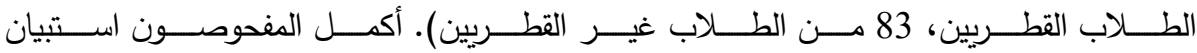

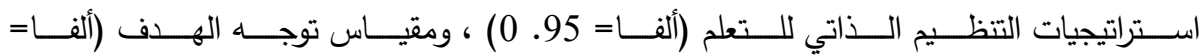

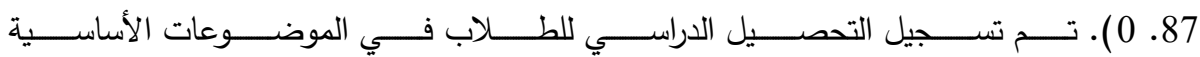

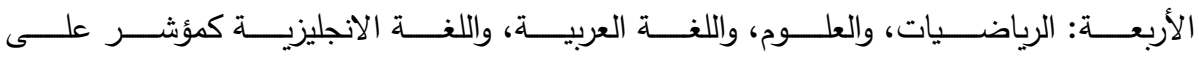

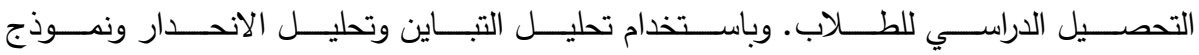

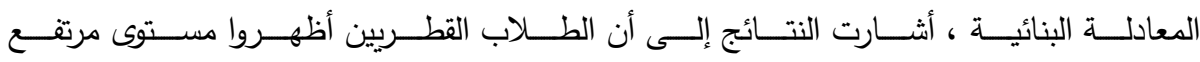

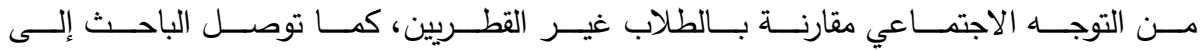

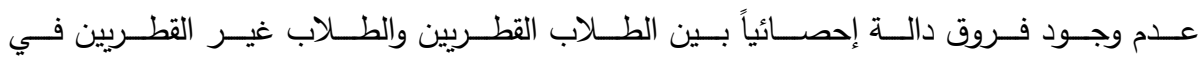

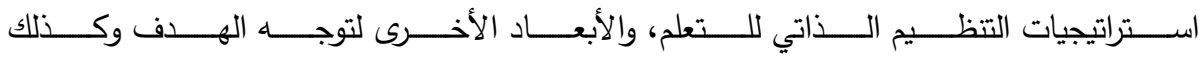

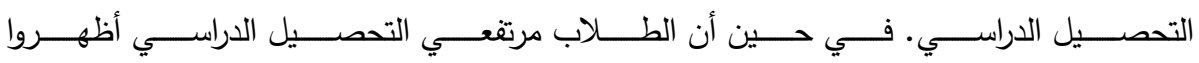

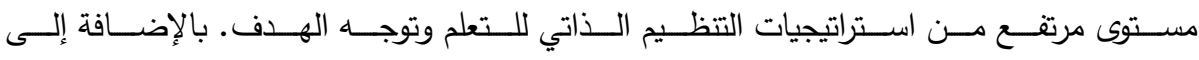

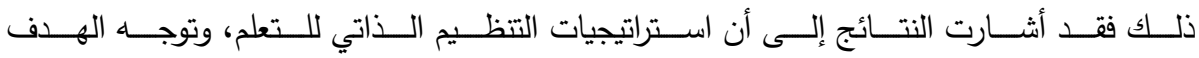

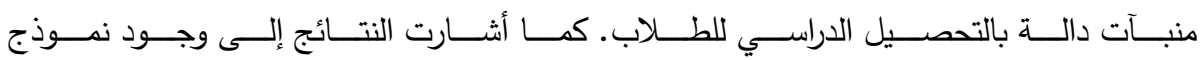

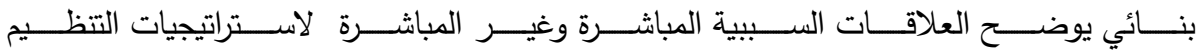

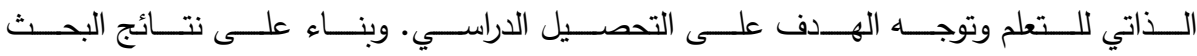




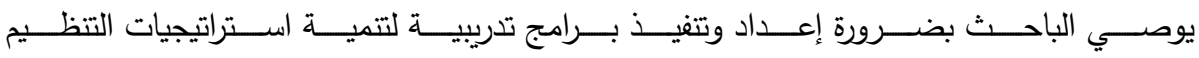

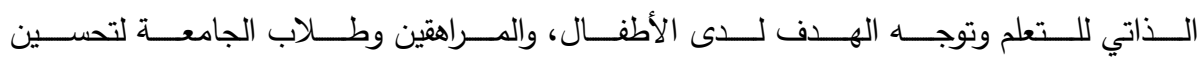

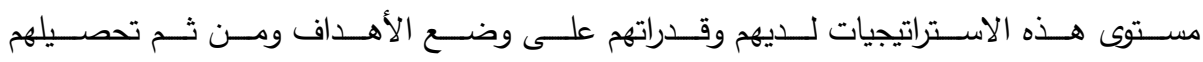
الدراسي.

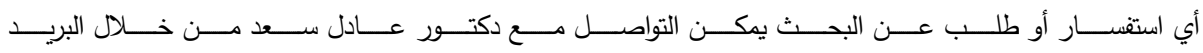
الالكتروني:ydelk22@yahoo.com

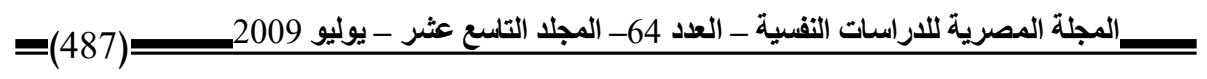

